\title{
Characterization of Vibriocin and Prospect of Co-Culture Method to Overcome the Diminishing Antibacterial Activity
}

\author{
V. H. Neha ${ }^{1}$, S. Visnuvinayagam ${ }^{2 *}$, L. N. Murthy ${ }^{3}$, A. Jeyakumari ${ }^{3}$ \\ G. K. Sivaraman ${ }^{2}$ and M. M. Prasad ${ }^{2}$ \\ ${ }^{1}$ Molecular \& Cell Biology, University of Texas at Dallas, W Campbell Rd, Richardson, \\ Texas-75080, USA \\ ${ }^{2}$ ICAR-Central Institute of Fisheries Technology, Cochin, Kerala, India \\ ${ }^{3}$ Mumbai Research Centre of ICAR-CIFT, Vashi, Navi Mumbai, Maharashtra, India \\ *Corresponding author
}

\section{A B S T R A C T}

\section{Keywords}

Vibriocin,

Bacteriocin,

Co-culture method,

Antibacterial activity

S. aureus

Article Info

Accepted:

07 September 2019

Available Online:

10 October 2019
The term 'Vibriocin' is specifically indicates the bacteriocin of Vibrio species. The present study reports the screening Vibriocin producing marine bacteria for food and aquaculture application. Out of 40 strains from Clam (Meretrix meretrix) species, screened against eight seafood borne pathogens, two Vibriocin producing bacteria were active against Staphylococcus aureus. Crude Vibriocin of these two isolates were subjected to salting-out for partial purification and exposed to different conditions i.e., $\mathrm{pH}$, temperature and detergent for its antibacterial activity. After few successive subcultures for characterization and bulk production, its antibacterial activity was decreased slowly and exhibited minimal antibacterial activity. Further, when the isolates were co-culture with $S$. aureus resulting in regain of antibacterial activity. This study revealed that Co-culture method is an appropriate approach to regain the Vibriocin production in Vibrio species and marine environment is a potential source of Vibriocin producing bacteria which can be exploited for various applications such as food preservation and as a probiotic for aquaculture ponds to control the pathogenic bacteria.

\section{Introduction}

Recent years, regulatory authorities are more stringent about incorporation of synthetic preservative in foods in order to control the spoilage and pathogenic bacteria. Hence, in future, the production of safety food is more difficult without a suitable alternative. Even though plant extracts, nanomaterials and oils are showing promising antibacterial properties (Viji et al.,2015; Visnuvinayagam et al., 2019), each product has their own limitations; 
moreover, it cannot be used for all processing methods. In recent year, recently, the application of bacteriocin in food as an emerging technique has gained considerable attention. Bacteriocin is secondary metabolite of bacteria and its application in the field of food preservation is termed as biopreservation. Even though, it is an active metabolite of bacteria, it is safe and can be used as an antibacterial for food preservation. A novel bacteriocin viz., Nisin (bacteriocin) has already been given the status of preservative by United States Food and Drug Administration (US-FDA) and is being used commercially in food industries (Sharma and Gautam, 2008). Hence, application of bacteriocin in fish would be a novel and promising platform to enhance the shelf life by eliminating the pathogenic and spoilage micro-flora in fish meat. Bacteriocins are substances having an essential biological protein moiety possess the bactericidal mode of action against other bacteria. It is considered as an immunity mechanism for the particular bacteria protects from other bacteria i.e., Bacteriocins may serve as anti-competitor compounds to protect the own microbial community. Generally, bacteriocins are ribosomally synthesised substance active against closely related bacterial species; but, rarely some bacteriocin can target a broader range of bacterial species (Bakkal et al., 2012). These bacteriocins sizes are varies from high molecular weight (like Colicin) to simple small peptides like Nisin (Sharma et al., 1984). The advantages of bacteriocin are nontoxic and non-antigenic to animals including humans; moreover it is easily degraded by the proteolytic enzymes of the gastrointestinal tract; hence, it is safe to incorporate in food (Desriac et al., 2010). Even though vast numbers of studies dealt bacteriocin, only limited studies are available on the Vibriocin. Hence, in the present study, Vibriocin was purified and characterized and its diminishing biological activity was effectively controlled by the modified coculture method.

\section{Materials and Methods}

\section{Isolation of Vibrios}

Live Clam species were collected from retail fish market of Vashi, Navi Mumbai and brought to laboratory and were processed for isolation of Vibrio species by inoculating the Clam's gut content into alkaline peptone water (APW) containing 2\% $\mathrm{NaCl}$ (Prasad et al., 2005) for enrichment. After overnight incubation, a loop full culture was taken from surface pellicle and streaked over ThiosulfateCitrate-Bile salts-Sucrose (TCBS) agar supplemented with $2 \% \mathrm{NaCl}$ and incubated at $37^{\circ} \mathrm{C}$. After overnight incubation, characteristic colonies were picked and inoculated into brain heat infusion (BHI) slant (with 2\%) for further biochemical characterization.

\section{Biochemical characterisation}

Isolated Vibrio cultures were tested by gram stain and confirmed the Vibrio genus by various biochemical tests viz., oxidase test, sensitivity against Vibrio-static agent O129, Arginine di-hydrolase, Ornithine decarboxylase and Lysine decarboxylase.

\section{Bio-screening}

The selected 40 isolates were grown in Brain Heat Infusion (BHI) broth containing 2\% $\mathrm{NaCl}$ and incubated at $37^{\circ} \mathrm{C}$. Further, the overnight cultures were centrifuged at 10,000 rpm for $15 \mathrm{~min}$ and the cell free supernatant (CFS) was passed through $0.22 \mu$ sterile syringe filter (Nowroozi et al., 2004). These sterile filtrates were used for well diffusion assay to screen Vibriocin production against eight food borne bacteria i.e., Aeromonas hydrophila, Bacillus cereus, Escherichia coli, 
Listeria monocytogenes, Salmonella, Staphylococcus aureus, Vibrio cholerae and Vibrio parahaemolyticus. For antibiogram assay, these pathogenic bacteria were grown in test tube and the concentrations of the cultures were adjusted to $0.5 \mathrm{McF}$ arland standard turbidity. In case of $S$. aureus and $V$. parahaemolyticus cultures, Mueller Hinton Agar with $2 \% \mathrm{NaCl}$ was used (CLSI, 2014). Wells of $6 \mathrm{~mm}$ diameter were made on $200 \mathrm{~mm}$ (diameter) agar plate by Cork-borer (HiMedia\# LA737) and then the bottom of the wells was sealed with sterile $1 \%$ agar in order to avoid the leakage. Finally, all the wells

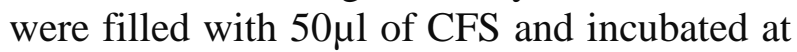
$37^{\circ} \mathrm{C}$. These plates were examined after $24 \mathrm{~h}$ for zone of inhibition (Fig. 1) with the aid of antibiotic zone scale.

\section{Partial purification of vibriocin}

CFS was precipitated by addition of ammonium sulphate into CFS fluid up to $60 \%$ saturation at $4^{\circ} \mathrm{C}$ for $6 \mathrm{~h}$ (Seatovic et al., 2011). The precipitates were collected by centrifugation at $10,000 \mathrm{rpm}$ for $20 \mathrm{~min}$. The pellet was re-suspended in $10 \mathrm{ml} 0.1 \mathrm{M}$ Tris buffer, $\mathrm{pH}$ 7.0.

The pellet obtained from $60 \%$ fraction was dialysed against distilled water for $6 \mathrm{~h}$ using $12 \mathrm{KDa}$ dialysis membranes (Jini et al., 2011). The partially purified Vibriocin was distributed in small quantity (aliquots) and stored in deep freezer $\left(-20^{\circ} \mathrm{C}\right)$ for further usage.

\section{Characterization of bacteriocin}

Stability of the Vibriocin was checked as per Singh et al., (2013) protocol by subjecting the bacteriocin with different proteolytic enzymes, temperature, $\mathrm{pH}$ and surfactant.

\section{Effect of $\mathbf{p H}$}

The aliquots of Vibriocin were adjusted to different $\mathrm{pH}$ i.e., from $2,4,6,8,10$ and 12 then kept at room temperature for 30 minutes. The same aliquots were neutralised to $\mathrm{pH} 7$ and antibiogram was carried out against $S$. aureus.

\section{Effect of temperature}

The effect of temperature on bacteriocin activity was tested by heating the Vibriocin aliquots at different temperatures from $40^{\circ} \mathrm{C}$ to $121^{\circ} \mathrm{C}$. Simultaneously, one aliquot was maintained as control by incubating the test sample at $37^{\circ} \mathrm{C}$ for better comparison.

Aliquots of each sample were taken after 15, 30, 60 and $90 \mathrm{~min}$, then the activity was assessed by well diffusion assay against $S$. aureus.

\section{Effect of proteolytic enzymes}

CFS was treated with Lysozyme, Papain and Proteinase K (each $1 \mathrm{mg} / \mathrm{ml}$ ) and incubated at $37^{\circ} \mathrm{C}$ for $1 \mathrm{~h}$ then the antibacterial activity was assessed by antibiogram (Pilasombut et al., 2006).

\section{Effect of surfactants}

Aliquots of Vibriocin was treated with surfactant viz., SDS and urea, in different concentrations $(0.25 \%, 0.5 \%$ and $1 \% \mathrm{w} / \mathrm{v})$ and incubated at $37^{\circ} \mathrm{C}$ for $2 \mathrm{~h}$ (Seatovic et al., 2011) and the antibacterial activity was checked.

\section{SDS-PAGE analysis}

The partial purified Vibriocin samples were further subjected to SDS-PAGE with 10\% running gel to determine the Molecular weight of the Vibriocin (Yamamuto et al., 2003). Electrophoresis was performed at $100 \mathrm{~V}$ for $1 \mathrm{~h}$ and the gel was stained overnight with Coomassie Brilliant Blue, then de-stained and checked for specific band. 


\section{Plasmid isolation}

Plasmid isolation was carried out as per Michael and Sambrook, (2012) to determine antimicrobial activity whether due to portion of bacterial genome or plasmid (Tolinacki et al., 2010).

Co-culture method to overcome the diminishing antibacterial activity

In the present study, the decreased in the antibacterial activity was observed. Hence, $100 \mu 1$ of $1 \mathrm{Mc}$ Farland standard turbidity culture of VPB was inoculated into the $10 \mathrm{ml}$ containing $0.5 \mathrm{Mc}$ Farland standard culture of $S$. aureus. After overnight incubation VPB was isolated by streaking over TCBS supplemented with $2 \% \mathrm{NaCl}$. Similarly, three passages were carried out and found a considerable improvement in the production of Vibriocin.

\section{Results and Discussion}

In the present study, a total of 40 Vibrio species were isolated from clam samples and confirmed based on biochemical characters. Further, all isolates were screened for Vibriocin production and observed that only 2 strains i.e., isolate number 7 and 8 were able produce Vibriocin, that could control the growth of S. aureus (Fig. 1). Between two strains, isolate Number 8 showed better inhibition than the isolate number 7. Hence, isolate number 8 was chosen for bulk production by inoculating into one litre $\mathrm{MH}$ Broth (supplemented with $2 \% \mathrm{NaCl}$ ) and CFS was subjected to partial purification by salting out using Ammonium sulphate. It was observed that the antimicrobial activity of the Vibriocin against $S$. aureus was enhanced after the purification (Fig. 2). Then the partially purified of Vibriocin producing strains were subjected to various biological conditions i.e., treated with different $\mathrm{pH}$, temperature, proteolytic enzymes and surfactant. While checking the activity at different level of $\mathrm{pH} 4$ to 8 , it was observed that the maximum activity at neutral $\mathrm{pH}$. Similarly, while subjecting to heat treatment, its activity was not lost even after $30 \mathrm{~min}$ at $60^{\circ} \mathrm{C}$; but inactivation occurred when the incubation was continued for a longer period. However, total loss of activity was observed after incubation at $80^{\circ} \mathrm{C}$. To study the stability with proteolytic enzymes, Vibriocin was treated with different proteolytic enzymes and found that complete loss of antimicrobial activity in agar plate. Addition of surfactant viz. Sodium dodecyl sulfate (SDS) with Vibriocin led to an enhanced zone of inhibition as compared to the SDS and untreated sample (Fig. 3). But, addition of urea with the Vibriocin leads to complete loss of the antimicrobial activity. The materials were again checked for SDS-PAGE analysis; but, no band could be observed. Isolate 8 was subjected to Alkaline lysine method a for plasmid isolation and found the there is no plasmid in the VPB. The antibacterial activity of the Vibriocin was diminished with frequent subculture in the MH agar. However with coculture method its diminishing antibacterial activity was reverted back to normal level.

Emergence of multi drug resistant bacteria was frequently reported in seafood sector (Visnuvinayagam et al., 2015, 2016, 2017, 2018). In the mean time the food controlling authority are more stringent in the addition of synthetic food substance in the food. So, this is the suitable period to find an alternative to the synthetic antibacterial substance. So in the present study the all Vibriocin was isolated and screened for the antibacterial activity. Bacteriocins in general, are mostly active against the closely related species. Ironically, in the present study, these two isolates were active against the Staphylococcus genus. Similarly, Balakrishnan et al., (2014) isolated a Vibriocin from Vibrio parahaemolyticus against pathogenic Vibrio harveyi and recommended for the food application. Even though, the isolated metabolite obtained from 
pathogenic $V$. parahaemolyticus, since it is only a metabolites (not bacteria as such), it is considered as safe for in food application. Even though Vibrio species are abundant in marine water as well as estuarine environment (Oliver and Kaper, 1997) reports are scant on Vibriocin production and characterization. However, voluminous data is available related to the other environments (Nowroozi et al., 2004; Singh et al., 2013; Olivera et al., 2014). Sugita et al.,(1997) isolated a VPB from the marine fish intestine and reported activity against Pasteurella piscicida. Shehane and Sizemore (2002) isolated three VPB from marine waters and which exhibited antibacterial activity against $V$. vulnificus, $V$. cholerae and $V$. parahaemolyticus. Carraturo et al., (2006) isolated Vibriocin from $V$. mediterranei-1 and found the antibacterial activity against $V$. parahaemolyticus.

The isolated Vibriocin was active between $\mathrm{pH}$ 4 to 8 . Since, most of the fish and other food products are belong to same $\mathrm{pH}$. It can be applied in food to control the S. aureus. In addition, it is fairly heat stable i.e., able to withstand $80^{\circ} \mathrm{C}$ similarly for short duration, it cannot be used for fresh fish.

It is suitable only after heat treatment or those foods not subjected to heat treatment. Sugita et al., (1997) reported that Vibriocin production was observed while growing the culture only between $15-25^{\circ} \mathrm{C}$; whereas, it did not produce the Vibriocin while growing $30-$ $35^{\circ} \mathrm{C}$. Antibacterial activity of the Vibriocin was assessed after treating with different enzymes and found that complete loss of antimicrobial activity. Similarly, Carraturo et al., (2006) observed that Vibriocin antimicrobial was degraded by the Proteinase $\mathrm{K}$; but it was resistant to trypsin and alphachymotrypsin. So, the isolates Vibriocin was highly sensitive to the proteolytic enzymes viz. lysozyme, papain and Proteinase K. In the continuation of the stability of the Vibriocin testing protocol, again the Vibriocin was treated with surfactant viz. Sodium dodecyl sulfate (SDS) and Urea. Interestingly, SDS treated Vibriocin exhibited drastic increase in zone of inhibition as compared to the SDS (alone) and untreated (Vibriocin alone) sample. Whereas urea treated Vibriocin did not exhibited any antibacterial activity, possibily due to the reason that urea cleaves the disulphide bonds present in the Vibriocin; so, thus it could be assumed that the Vibriocin compound contains a disulphide bond which has been cleaved by urea. The, presence of disulphide bond is highly essential for the action of the Vibriocin species.

Similarly, Elayaraja et al., (2014) reported that vibriocin was moderately resistant to SDS and highly sensitive to Urea. In the present study, the Vibriocin was able to inhibit the only $S$. aureus species, which indicates the narrow killing ability of the Vibriocin towards $S$. aureus alone.

This narrow killing ability of particular pathogens would give an added advantage i.e., it limits the ability of bacteria to evolve resistance to the antimicrobials and thus reduces the incidence of drug-resistant pathogens. Hence, it can be applied to foods by spray-drying as either dried bacteriocins or probiotic bacteriocinogenic strains (Bakkal et al., 2012). For example, Brillet et al., (2005) has shown that bacteriocin producer Carnobacterium divergens V41 can be used as a bio-preservative to inhibit the growth of Listeria monocytogenes in cold smoked salmon. Similarly, Schobitz et al., (1999) directly applied a BLIS from Carnobacterium piscicola into vacuum-packed meat, which inhibited the growth of $L$. monocytogenes in the vacuum-packed meat after 14 days of storage at $4^{\circ} \mathrm{C}$ (Carraturo et al., 1999). 
Fig.1 Screening of the Vibriocin producing isolates by well diffusion assay in 200mm antibiogram plate; zone of clearance around isolate no. 8

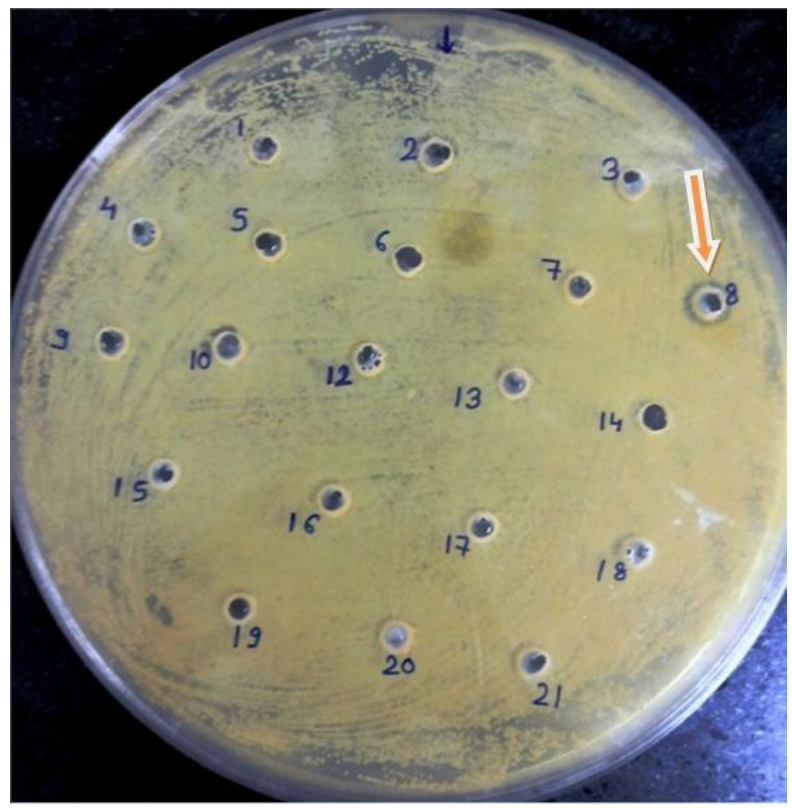

Fig.2 Partially purified Vibriocin exhibiting enhanced zone of inhibition in well diffusion assay

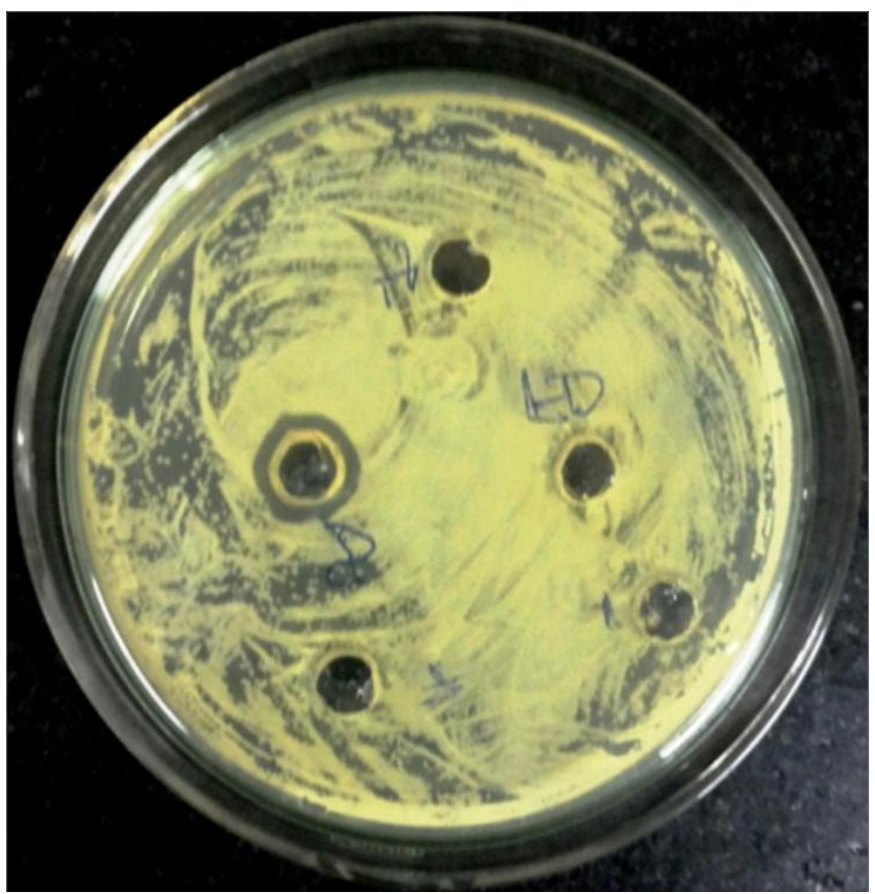

Fig.3 Enhanced activity of the Vibriocin after treatment with SDS different concentration; well no. 12 is untreated Vibriocin; well no. 8 is SDS control, Well no. 3,4 and 7 are the SDS treated Vibriocin with different concentration 


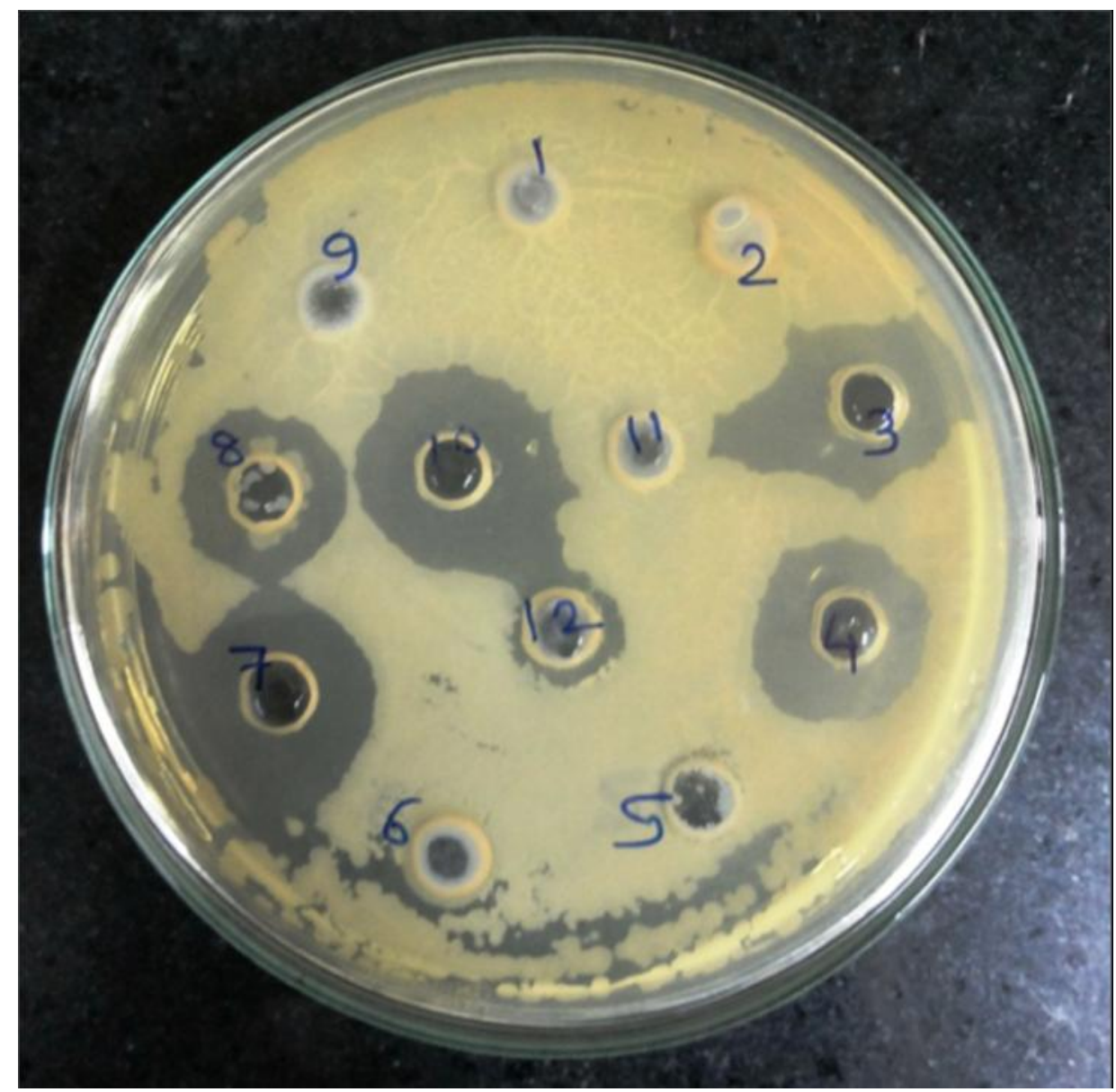

These studies aid in the argument that bacteriocins should be used as a biopreservation technique in the seafood industry. This technology has already emerged in the terrestrial food industry as we see with nisin (FDA approved food additive) and MicrogardTM (a milk-based BLIS). It has also been suggested that bacteriocins could be combined with current methods of antimicrobial treatment and preservation to produce synergistic effects, such as incorporating bacteriocins into bio-active packaging (Pilet et al., 2011). For instance, bacteriocins can be impregnated into gel coatings and/or polyethylene films and can be applied to seafood during packaging (Neetoo et al., 2008). In fact, immobilization of bacteriocins on coating materials for biopreservation may actually reduce the cost of packaging due to the reduced amount and cost of the antibacterial materials needed to attach to the film (Galvez et al., 2008). Creating combinations of bacteriocins and current methods used in the seafood industry has the potential to increase the guarantee of freshness by assuring the inhibition of spoilage causing microorganisms.

In the present study, the antibacterial activity was reduced with sub culturing. Similarly, Vriezen et al., (2009) reported that reduction of inhibition activity with continued subculture in the non competitive media. The Colicin producing bacteria was subcultured upto 253 times (generation) and proved that, reduction in the killing ability of the bacteria while increasing the passaging/ subculturing/ generation and they identified that the change in gene expression (up regulation) and significant change in DNA repair mechanism 
(down regulation). In the present study too. The decrease in antibacterial activity may be due to repeated subculture without any competitive medium. So, based on the suggestion, competition was created in the media i.e., A $\mathrm{MH}$ broth containing fairly grown culture of the $S$. aureus was chosen as an inhibitory media for VPB. Similarly, Mearns-Spragg et al., (1998) observed that the increased production of the antimicrobial compound while marine bacteria co-cultured with live bacteria (Pseudomonas aeruginosa and Escherichia coli) or inactivated (killed cells of $S$. aureus) bacteria.Reports published by Slattery et al., (2001) also supported that in passaging the culture in the competitive media leads to increase in primary and secondary metabolites. Since, Vibriocin also one of the metabolites, competitive media facilitated increase in the production of Vibriocin.

Hitherto, most of the research studies on bacteriocin are based in pure cultures; but, in natural ecosystem it is too complex and significance in the gene responses can be observed In the present study, the VPB were isolated from Clams and after successive passages for characterization study, it's antibacterial activity was lost. Based on coculture method its activity was reappeared. Similarly, Dusane et al., (2011) isolated different bacteria from the Green mussel and found that these enhanced antibacterial activity after co-culture method.

The study indicates that marine environment is one of the excellent sources of VPB (Singh et $a l .$, 2013). But, it was not elaborately dealt on revival of its lost antibacterial activity. Hence, the present study centred as overcoming the vanished antibacterial activity. Since, the use of prophylactic antibiotics is detrimental to aquatic and terrestrial environments, animal and human health bacteriocinogenic bacterial strains appear to be an excellent candidate for a friendly alternative, which will support the

industrial scaling up of production. Based on the microbial sequencing, many of the researchers observed that the very high in biosynthesis activity its fermentation production (Udwary et al., 2007). Especially, few bacterial and fungal species i.e., Aspergilli and actinomycetes are carrying a huge genomic resources/backup for the alternative metabolic pathway (Knight et al., 2003).

Hitherto, most of the studies followed a simultaneous co-culture method for the enhancement of biological activity; but, in the present study, a minor modification from the simultaneous co-culture method was followed. i.e., After the sufficient grown culture of $S$. aureus in $5 \mathrm{~mL}$ of $\mathrm{MH}$ broth (1Mc Farland turbidity), $100 \mu \mathrm{l}$ of $0.5 \mathrm{Mc}$ Farland turbidity concentration of VPB were inoculated and incubated at $37^{\circ} \mathrm{C}$. After overnight incubation, the loop full culture was streaked over TCBS agar for isolation of VPB. The same procedure was repeated twice to regain its antimicrobial activity. Interaction, between the bacterial and fungus species also causes increased production of the active metabolite. Miao et al.,(2006) reported that most of the time, after co -culture with other bacteria, identified which is due to silence most of the time while in pure culture and also reported that the enhanced antibacterial activity of the while adding the cell free extract of the bacterial broth.

Based on the present study findings, it is concluded that marine water is a potent source of Vibriocin and the isolated Vibriocin can be used to control the $S$. aureus in the food. Antibacterial activity of the Vibriocin can be regained or increased by co-culture application.

\section{References}


Bakkal, S., Robinson, S.M. and Riley, M.A., 2012. Bacteriocins of aquatic microorganisms and their potential applications in the seafood industry. In Health and environment in aquaculture. IntechOpen. Pp. 303- 328

Balakrishnan, B., Ranishree, J.K., Thadikamala, S. and Panchatcharam, P., 2014. Purification, characterization and production optimization of a vibriocin produced by mangrove associated Vibrio parahaemolyticus. Asian Pacific journal of tropical biomedicine, 4(4), pp.253261.

Brillet, A., Pilet, M.F., Prevost, H., Cardinal, M. and Leroi, F., 2005. Effect of inoculation of Carnobacterium divergens V41, a biopreservative strain against Listeria monocytogenes risk, on the microbiological, chemical and sensory quality of cold-smoked salmon. International journal of food microbiology, 104(3), pp.309-324.

Carraturo, A., Raieta, K., Ottaviani, D. and Russo, G.L., 2006. Inhibition of Vibrio parahaemolyticus by a bacteriocin- like inhibitory substance (BLIS) produced by Vibrio mediterranei 1 . Journal of applied microbiology, 101(1), pp.234-241.

CLSI, 2014. Clinical and Laboratory Standards Institute Performance Standards for Antimicrobial Susceptibility Testing; Twenty-Fourth Informational Supplement, CLSI document M100-S24, Wayne.

Desriac, F., Defer, D., Bourgougnon, N., Brillet, B., Le Chevalier, P. and Fleury, Y., 2010. Bacteriocin as weapons in the marine animal-associated bacteria warfare: inventory and potential applications as an aquaculture probiotic. Marine drugs, 8(4), pp.1153-1177.

Dusane, D.H., Matkar, P., Venugopalan, V.P., Kumar, A.R. and Zinjarde, S.S., 2011. Cross-species induction of antimicrobial compounds, biosurfactants and quorumsensing inhibitors in tropical marine epibiotic bacteria by pathogens and biofouling microorganisms. Current microbiology, 62(3), pp.974-980.

Elayaraja, S., Annamalai, N., Mayavu, P. and Balasubramanian, T., 2014. Production, purification and characterization of bacteriocin from Lactobacillus murinus AU06 and its broad antibacterial spectrum. Asian Pacific journal of tropical biomedicine, 4, pp.S305-S311.

Galvez, A., López, R.L., Abriouel, H., Valdivia, E. and Omar, N.B., 2008. Application of bacteriocins in the control of foodborne pathogenic and spoilage bacteria. Critical reviews in biotechnology, 28(2), pp.125-152.

Knight, V., Sanglier, J.J., DiTullio, D., Braccili, S., Bonner, P., Waters, J., Hughes, D. and Zhang, L., 2003. Diversifying microbial natural products for drug discovery. Applied Microbiology and Biotechnology, 62(5-6), pp. 446-458.

Mearns- Spragg, A., Bregu, M., Boyd, K.G. and Burgess, J.G., 1998. Cross- species induction and enhancement of antimicrobial activity produced by epibiotic bacteria from marine algae and invertebrates, after exposure to terrestrial bacteria. Letters in Applied Microbiology, 27(3), pp.142-146.

Miao, L.I., Kwong, T.F. and Qian, P.Y., 2006. Effect of culture conditions on mycelial growth, antibacterial activity, and metabolite profiles of the marine-derived fungus Arthrinium cf saccharicola. Applied microbiology and biotechnology, 72(5), pp.1063-1073.

Michael R. G. and Joseph Sambrook, 2012. Molecular Cloning A Laboratory Manual, Molecular Cloning, A Laboratory Manual, 4th Edition, www.molecularcloning.org Cold Spring Harbor Protocols.

Neetoo, H., Ye, M., Chen, H., Joerger, R.D., Hicks, D.T. and Hoover, D.G., 2008. Use of nisin-coated plastic films to control Listeria monocytogenes on vacuum-packaged cold-smoked salmon. International journal of food microbiology, 122(1-2), pp.8-15.

Nowroozi, J., Mirzaii, M. and Norouzi, M., 
2004. Study of Lactobacillus as probiotic bacteria. Iranian Journal of Public Health, 33 (2), 1-7.

Oliver, J.D. and Kaper, J.B. 1997, Vibrio species. In Food Microbiology: Fundamentals and Frontiers ed. Doyle, M.P. pp. 228-264. Washington, DC: ASM Press.

Olivera, N. and Rodríguez, M. 2014. Lactic Acid Bacteria Isolated From Fish Gut Produce Conjugated Linoleic Acid Without The Addition Of Exogenous Substrate, Process Biochemistry: 10711077.

Pilasombut, K., Sakpuaram, T., Wajjwalku, W., Nitisinprasert, S., Swetwiwathana, A., Zendo, T., Fujita, K., Nakayama, J. and Sonomoto, K., 2006. Purification and amino acid sequence of a bacteriocins produced by Lactobacillus salivarius K7 isolated from chicken intestine. Songklanakarin J Sci Technol, 28 (Suppl 1), pp.121-31.

Pilet, M.F. and Leroi, F., 2011. Applications of protective cultures, bacteriocins and bacteriophages in fresh seafood and seafood products. In Protective cultures, antimicrobial metabolites and bacteriophages for food and beverage biopreservation (pp. 324-347). Woodhead Publishing.

Prasad, S., Morris, P.C., Hansen, R., Meaden, P.G. and Austin, B., 2005. A novel bacteriocin-like substance (BLIS) from a pathogenic strain of Vibrio harveyi. Microbiology, 151(9), pp.3051-3058.

Schöbitz, R., Zaror, T., León, O. and Costa, M., 1999. A bacteriocin from Carnobacterium piscicola for the control of Listeria monocytogenes in vacuumpackaged meat. Food microbiology, 16(3), pp.249-255.

Seatovic, S.L., Jovanović-Novaković, J.S., Zavisic, G.N., Radulovic, Z.C., Gavrović-Jankulović, M. and Jankov, R.M., 2011. The partial characterization of the antibacterial peptide bacteriocin $\mathrm{G}$ (2) produced by the probiotic bacteria Lactobacillus plantarum G (2). Journal of the Serbian chemical society, 76(5), pp.699-707.

Sharma, J.K., Malik, R.K. and Mathur, D.K., 1984. Isolation and identification of proteolytic psychrotrophic sporeforming bacteria from raw milk supplies at an experimental dairy in India. International Journal of Dairy Technology, 37(3), pp. 96-98.

Sharma, N. and Gautam, N., 2008. Antibacterial activity and characterization of bacteriocin of Bacillus mycoides isolated from whey. Indian Journal Of Biotechnology (7): 117-121.

Shehane, S.D. and Sizemore, R.K., 2002. Isolation and preliminary characterization of bacteriocins produced by Vibrio vulnificus. Journal of applied microbiology, 92(2), pp.322328.

Singh, P.K., Sharma, V., Patil, P.B. and Korpole, S., 2012. Identification, purification and characterization of laterosporulin, a novel bacteriocin produced by Brevibacillus sp. strain GI9. PloS one, 7(3), p.e31498.

Singh, R., Sivasubramani, K., Jayalakshmi, S., Kumar, S.S. and Selvi, C., 2013. Isolation and production of bacteriocin by marine Lactobacillus fermentum SBS001. Int. J. Curr. Microbiol. Appl. Sci, 2, pp.67-73.

Slattery, M., Rajbhandari, I. and Wesson, K., 2001. Competition-mediated antibiotic induction in the marine bacterium Streptomyces tenjimariensis. Microbial Ecology, 41(2), pp.90-96.

Sugita, H., Matsuo, N., Hirose, Y., Iwato, M. and Deguchi, Y., 1997. Vibrio sp. strain NM 10, isolated from the intestine of a Japanese coastal fish, has an inhibitory effect against Pasteurell.

Tolinacki, M., Kojic, M., Lozo, J.E.L.E.N.A., Terzic-Vidojevic, A., Topisirovic, L. and Fira, D., 2010. Characterization of the bacteriocin-producing strain Lactobacillus paracasei subsp. paracasei BGUB9. Arch Biol Sci, 62(4), pp.889-899. 
Udwary, D.W., Zeigler, L., Asolkar, R.N., Singan, V., Lapidus, A., Fenical, W., Jensen, P.R. and Moore, B.S., 2007. Genome sequencing reveals complex secondary metabolome in the marine actinomycete Salinispora tropica. Proceedings of the National Academy of Sciences, 104(25), pp.10376-10381.

Viji, P., Binsi, P.K., Visnuvinayagam, S., Bindu, J., Ravishankar, C.N. and Gopal, T.K.S., 2015. Efficacy of mint (Mentha arvensis) leaf and citrus (Citrus aurantium) peel extracts as natural preservatives for shelf life extension of chill stored Indian mackerel. Journal of food science and technology, 52(10), pp.6278-6289.

Visnuvinayagam S., Joseph T.C., Murugadas, V., Chakrabarti, R., and Lalitha, K.V., 2015. Status on methicillin resistant and multiple drug resistant Staphylococcus aureus in fishes of Cochin and Mumbai coast, India. Journal of Environmental Biology, 36(3):571.

Visnuvinayagam S., Murthy L.N., Parvathy U., Jeyakumari A., Adiga T.G., Sivaraman G.K., 2018. Detection of multi drug resistant bacteria in retail fish market water samples of Vashi, Navi Mumbai. Proceedings of the National Academy of Sciences, India Section B: Biological Sciences, 89(2):559-64.
Visnuvinayagam S., Murthy L.N., Viji P, Sivaraman G.K., 2017. Study on retail fish markets: Possible occurrence and transmission of emerging pathogen from faecal indicators. Journal of Environmental Biology, 38, 465 - 470.

Visnuvinayagam, P., Viji, P., Murthy, L.N., Jeyakumari, A. and Sivaraman, G.K., 2016. Occurrence of faecal indicators in freshwater fishes of Navi Mumbai in retail outlets. Fishery Technology, 53; 334-338.

Visnuvinayagam, S., Murthy, L.N., Jeyakumari, A., Parvathy, U., Anandan, R., Sivaraman, G.K. and Ravishankar, C.N., 2019. Combined effect of zinc oxide nano particle incorporated chitosan for better antimicrobial activity towards wound healing. Journal of Environmental Biology, 40(4), pp.691697

Vriezen, J.A., Valliere, M. and Riley, M.A., 2009. The evolution of reduced microbial killing. Genome biology and evolution, 1, pp.400-408.

Yamamoto, Y., Togawa, Y., Shimosaka, M. and Okazaki, M., 2003. Purification and characterization of a novel bacteriocin produced by Enterococcus faecalis strain RJ-11. Appl. Environ. Microbiol., 69(10), pp.5746-5753.

\section{How to cite this article:}

Neha, V. H., S. Visnuvinayagam, L. N. Murthy, A. Jeyakumari, G. K. Sivaraman and Prasad, M. M. 2019. Characterization of Vibriocin and Prospect of Co-Culture Method to Overcome the Diminishing Antibacterial Activity. Int.J.Curr.Microbiol.App.Sci. 8(10): 671-681. doi: https://doi.org/10.20546/ijcmas.2019.810.076 